\title{
Fluorosis: An Endemic Disease
}

\author{
Sakshi Chaturvedi ${ }^{1}$, Chakrapani Chaturvedi ${ }^{2}$ \\ ${ }^{1}$ Assistant Prof., Banasthali Vidyapith, Niwai, Dist. Tonk (Raj), ${ }^{2}$ Associate Prof. cum Principal, B.V.M Nursing College \\ Gwalior
}

\begin{abstract}
A study is conducted to assess the cases of fluoride affected person in selected gram panchayat, Tonk ,Rajasthan. This study is conducted as perspective to conduct action research after wards. In This study symptoms of fluoride has been categorized in three type of fluorosis skeletal( SKF ), non skeletal fluorosis (NSKF) and dental fluorosis (DF).In this study villagers between the age group 10-70 years were observed for the presence of fluorosis symptoms by researchers. Conclusion of the study is level of fluoride in the water or food and crops grown in that majorily has caused non skeletal fluorosis, $50 \%$ people are affected severely ,2\% population study sample has developed severe skeletal fluorosis , $56 \%$ sample is affected with dental fluorosis at moderate level among which children are more affected after conducted assessment of fluorosis symptoms in fluoride endemic district, researcher has given health education to study sample and discussed many nutritional and environmental manipulations which can decrease the level of fluoride in human body as well as in ground water level
\end{abstract}

Key Words: Dental Fluorosis, Skeletal Fluorosis, Non Skeletal Fluorosis, Fluoride

\section{Introduction}

Fluorosis is a disease of oral, skeletal and non skeletal dysfunction which arises due to increase fluoride level $>1.5 \mathrm{mg}$ /liter in ground water and increase fluorine gas in atmospheric air $^{3}$. In North India Rajasthan and Gujarat and in South India Andhra Pradesh are highly endemic areas. Punjab, Haryana, M.P, Maharashtra are moderately endemic areas. Tamilnadu, West Bengal, Uttar Pradesh, Bihar and Assam are mildly affected endemic area of fluorosis. Fluorosis is essentially Hydrofluorosis except in parts of Gujarat and UP where industrial fluorosis also seen Which is due to fluoric acid compounds. The food and crop which is grown locally among fluoride endemic area is also found to have very high fluoride level (Richa Miglani ,2018). WHO has classified FLUOROSIS among 3 categories DENTAL FLUOROSIS, SKELETAL

\section{Corresponding Author:}

\section{Chakrapani Chaturvedi}

Banasthali vidyapith Mahadevi Niwas-11 Flat No. 215, Banasthali ,Niwai ,dist. Tonk (Raj) pin;

E-mail: chaturvedimrssakshi@gmail.com
FLUOROSIS, NON SKELETAL FLUOROSIS, In Non Skeletal Fluorosis GIT system shows Acute abdominal pain, Diarrhea,Constipation, blood in Stool, Bloated feeling (Gas), Tenderness in Stomach, Feeling of nausea. Nervous system when affected with high fluoride concentration shows NERVOUSNESS \& DEPRESSION, tingling sensation in fingers and toes, Excessive thirst and tendency to urinate ,Frequently Polydypsia and polyuria control by brain appears to be adversely affected. Some studies reported infertility in humans and menstrual disturbance in women is also observed due to effect of high fluoride level on thyroid gland.

Research Reviews suggests that high fluoride more than $10 \mathrm{mg} /$ liter in drinking water and daily activity for prolong period of time can also affect skeletal system which is termed as Skeletal Fluorosis[3] causing multiple bone and joint pain, tingling ,burning and pricking sensation in limbs, chronic fatigue, muscle weakness. Changes can be observed in spinal column and pelvis. In later stages osteoporosis and bone spur can be developed and crippling Skeletal Fluorosis is also observed due to fusion of vertebra and bones. Dental fluorosis occurs 
due to exposure to fluoride during mineralization; fluoride replaces the hydroxyapatite crystals in teeth and gets deposited as fluorapatite crystals, which becomes clinically visible as dental mottling. Mottling of the teeth is usually seen in younger children who are developing their front teeth. Excessive fluoride also replaces the hydroxyl groups present in the hydroxyapatite crystal of the bone, forming fluorapatite. This has large crystal size due to which the bone becomes brittle and susceptible to fracture risk. Moreover, young bones retain more fluoride than older bones. Clinical manifestations of fluorosis may be aggravated by malnutrition, specifically calcium and vitamin D nutrition status which is evident from the high incidence of crippling deformities in poor residents from endemic fluorosis zones ${ }^{[5]}$ in dental fluorosis tooth enamel starts

\section{Material and Method}

The Research Design study for the present study is descriptive in nature which emphasize on prevalence of symptoms of Fluorosis among the person who are consuming fluoride water for more than 10 years regularly. Multi stage sampling is done. Village is divided in to Dhani non randomly and then 3 Dhanis are selected randomly among that all person in the age group10-70 years are interviewed from self structured questionnaire checklist for identification of fluorosis in an endemic area. Privacy of all participants is maintained as part of ethical consideration while interviewing. 100 persons were observed for presence of symptom related to fluorosis on the basis of pre validated self structured questionnaire check list given below. A health talk program was organized in which caused of fluorosis, identification of fluorosis, environmental manipulation such as tulsi (osmium) plant ${ }^{[2]}$, diet modification such as antioxidant rich food, vitamin $\mathrm{C}$ rich diet and treated water benefits are discussed .

Findings- Descriptive Statistics reveals that among all type of Fluorosis Non Skeletal Fluorosis has affected severely to $50 \%$ villagers, $24 \%$ villagers are moderately affected ,18\% villagers are mildly affected with NSKF and $8 \%$ have no problem related to NSKF. The Picture of skeletal fluorosis is seen severely in $2 \%$ cases which are already diagnosed for fluorosis, $17 \%$ villagers showed moderate level ,73\% showed mild level of SKF which is for pain some joints some time and sound coming after movement of those joint and $8 \%$ do not have any problem in skeletal system. Dental Fluorosis was seen moderately among $56 \%$ sample especially in age group $31-50,25 \%$ were mild Cases, $19 \%$ were having no dental problems.

Table1.1 Findings of selected socio-demographic variables

\begin{tabular}{|c|c|c|c|c|c|}
\hline \multirow{2}{*}{$\begin{array}{l}\text { S.no. } \\
\\
1 .\end{array}$} & \multirow{2}{*}{$\begin{array}{l}\text { Name of Socio } \\
\text { Demographic Variable } \\
\text { AGE }\end{array}$} & \multicolumn{2}{|c|}{ Classification } & \multicolumn{2}{|c|}{$\begin{array}{l}\text { Frequency and percentage } \\
n=100\end{array}$} \\
\hline & & & $\begin{array}{l}10-31 \\
31-50 \\
50-70\end{array}$ & $\begin{array}{l}42 \\
34 \\
24\end{array}$ & $\begin{array}{l}42 \% \\
34 \% \\
24 \%\end{array}$ \\
\hline 2. & Gender & & $\begin{array}{l}\text { Male } \\
\text { Female }\end{array}$ & $\begin{array}{l}64 \\
36\end{array}$ & $\begin{array}{l}64 \% \\
36 \%\end{array}$ \\
\hline 3. & Education & & $\begin{array}{l}\text { Illiterate } \\
\text { Primary } \\
\text { Middle } \\
\text { matric } \\
\text { Sr. sec. } \\
\text { Graduate } \\
\text { Certificate/diploma } \\
\text { Post graduate }\end{array}$ & $\begin{array}{l}19 \\
16 \\
18 \\
15 \\
6 \\
9 \\
12 \\
5\end{array}$ & $\begin{array}{l}19 \% \\
16 \% \\
18 \% \\
15 \% \\
6 \% \\
9 \% \\
12 \% \\
5 \%\end{array}$ \\
\hline
\end{tabular}


Cont... Table1.1 Findings of selected socio-demographic variables

\begin{tabular}{|c|c|c|c|c|c|}
\hline 4. & $\begin{array}{l}\text { Duration of consuming } \\
\text { fluoride water }\end{array}$ & $\begin{array}{l}\text { a) } \\
\text { b) } \\
\text { c) } \\
\text { d) } \\
\text { e) }\end{array}$ & $\begin{array}{l}10 \text { years } \\
15 \text { years } \\
20 \text { years } \\
25 \text { years } \\
\text { more than } 25 \text { years }\end{array}$ & $\begin{array}{l}14 \\
22 \\
30 \\
19 \\
15\end{array}$ & $\begin{array}{l}14 \% \\
22 \% \\
30 \% \\
19 \% \\
15 \%\end{array}$ \\
\hline 5. & Source of water & & $\begin{array}{l}\text { Well } \\
\text { Water plant } \\
\text { Pond }\end{array}$ & $\begin{array}{l}66 \\
12 \\
22\end{array}$ & $\begin{array}{l}66 \% \\
12 \% \\
22 \%\end{array}$ \\
\hline 6. & Occupation & $\begin{array}{l}\text { a) } \\
\text { b) } \\
\text { c) } \\
\text { d) } \\
\text { e) } \\
\text { f) }\end{array}$ & $\begin{array}{l}\text { Farming } \\
\text { Business } \\
\text { Labor } \\
\text { Private job } \\
\text { Govt. job } \\
\text { Dependent }\end{array}$ & $\begin{array}{l}25 \\
23 \\
19 \\
14 \\
4 \\
15\end{array}$ & $\begin{array}{l}25 \% \\
23 \% \\
19 \% \\
14 \% \\
4 \% \\
15 \%\end{array}$ \\
\hline 7. & History of smoking & $\begin{array}{l}\text { YES } \\
\text { NO }\end{array}$ & & $\begin{array}{l}44 \\
56\end{array}$ & $\begin{array}{l}44 \% \\
56 \%\end{array}$ \\
\hline 8. & $\begin{array}{l}\text { Conservation of rain water } \\
\text { at home }\end{array}$ & $\begin{array}{l}\text { YES } \\
\text { NO }\end{array}$ & & $\begin{array}{l}2 \\
98\end{array}$ & $\begin{array}{l}2 \% \\
98 \%\end{array}$ \\
\hline
\end{tabular}

\section{Discussion}

Data Suggests That NSKF is more prevalent among villagers. adults in age group 31-50 have developed dental fluorosis as well as non skeletal fluorosis .skeletal fluorosis is seen in elderly in complicate stage .only a few persons after leg deformity diagnosed with history of fluorosis. Significance related to consumption of fluoride drinking water more than 20 years and source of water well and pond suggests that these are the major contributory risk factor for fluorosis.

\section{Conclusion}

Researcher conclude that people who are drinking fluoride water more than 10 years will develop fluorosis symptoms which will turn in to life threatening issues paraplegia, sclerosis, osteoporosis. .use of filtered water, supplied water and environmental manipulation ${ }^{[2]}$ can decrease the fluoride level in ground water.

Conflict of Interest -None

Source of Funding- By Self

Acknowledgment -We are really thankful to hospital medical and nursing staff who had directly and indirectly contributed in our research.

Ethical Clearance - Informed consent has been taken up by all participants and Sarpanch has given permission to conduct the Study .

\section{References}

1. Amid I. Ismail.Fluoride supplements, dental caries and fluorosis A systematic review .JADA. 2008; 139 .

2. Sharma J.D., Bhinda S., Sharma P.K., Kumari M. And Boriwal R. therapeutic efficacy of medicinal plants to mitigate fluorosis. J Global Biosciences 2014; 3(5):802-807.

3. Arlappan, Atif Qureshi I, Srinivas R . Fluorsis in india An overview- Int. J Research and Developmental of Health 2013; 1(2) :97-102.

4. P.V. Kotecha, S.V. Patel, K.D Bhalani, D shah, V.S.Shah and K.G. Mehta .Prevalance of dental flurosis and dental caries in association with high levels of drinking water fluroid content in a district of Gujrat.Indian Journal of Medical Research India 
2012;873-877.

5. Prerna P Patel, Pinal A Patel, M Mughal Z et al Association of dental and skeletal fluorosis with calcium intake and serum vitamin D concentration in adolescents from a region endemic for fluorosis. Indian Journal of Endocrinology and
Metabolism2017; 190-195.

6. Manumanthu VR, Puvvadi G, Gouder MP, et al.Evaluation of Effect of Brushite-Calcite and Two Indigenous Herbs in Removal of Fluoride from Water. Journal of clinical and Diagnostic Research (2016) ;(10) :ZC83 - ZC85. 